\title{
Pretreatment with obestatin inhibits the development of acetic acid-induced colitis in rats
}

\author{
Aleksandra Matuszyk ${ }^{1,2}$, Piotr Ceranowicz ${ }^{1}$, Zygmunt Warzecha ${ }^{1}$, Jakub Cieszkowski ${ }^{1}$, \\ Krystyna Gałązka ${ }^{3}$, Joanna Bonior ${ }^{4}$, Jolanta Jaworek ${ }^{4}$, Peter Christopher Konturek ${ }^{5}$, Krzysztof Gil ${ }^{6}$, \\ Artur Dembiński ${ }^{1}$
}

\author{
${ }^{1}$ Department of Physiology, Faculty of Medicine, Jagiellonian University \\ Medical College, Krakow, Poland \\ 2Department of Anatomy, Faculty of Medicine, Jagiellonian University Medical College, \\ Krakow, Poland \\ ${ }^{3}$ Department of Pathomorphology, Faculty of Medicine, Jagiellonian University \\ Medical College, Krakow, Poland \\ ${ }^{4}$ Department of Medical Physiology, Faculty of Health Sciences, Jagiellonian University \\ Medical College, Krakow, Poland \\ ${ }^{5}$ Department of Internal Medicine II, Thuringia-Clinic Saalfeld, Teaching Hospital \\ of the University of Jena, Saalfeld, Germany \\ ${ }^{6}$ Department of Pathophysiology, Faculty of Medicine, Jagiellonian University \\ Medical College, Krakow, Poland
}

Submitted: 2 November 2015

Accepted: 22 January 2016

Arch Med Sci 2018; 14, 4: 920-929

DOI: https://doi.org/10.5114/aoms.2016.58749

Copyright (c) 2016 Termedia \& Banach

\section{Abstract}

Introduction: Obestatin is a 23-amino acid peptide derived from proghrelin, a common prohormone for ghrelin and obestatin. Previous studies have shown that obestatin exhibits some protective and therapeutic effects in the pancreas and stomach. The aim of this study was to examine the effect of pretreatment with obestatin on the development of acetic acid-induced colitis.

Material and methods: Studies were performed on Wistar rats. Before induction of colitis, rats were treated intraperitoneally with saline or obestatin, administered twice at a dose of 4,8 or $16 \mathrm{nmol} / \mathrm{kg} / \mathrm{dose}$. The first dose of saline or obestatin was administered $8 \mathrm{~h}$ before the induction of colitis, the second one $7 \mathrm{~h}$ after the first dose. Colitis was induced by enema with $1 \mathrm{ml}$ of $4 \%$ acetic acid solution. The severity of colitis was assessed 1 or $24 \mathrm{~h}$ after administration of enema.

Results: Pretreatment with obestatin administered at a dose of 8 or $16 \mathrm{nmol} /$ $\mathrm{kg} /$ dose significantly reduced the area of mucosal damage evoked by enema with acetic acid $(p<0.05)$. This effect was accompanied by an improvement of mucosal blood flow and DNA synthesis in the colon. Moreover, obestatin administered at a dose of 8 or $16 \mathrm{nmol} / \mathrm{kg} /$ dose significantly reduced mucosal concentration of IL-1 $\beta$ and activity of myeloperoxidase $(p<0.05)$.

Conclusions: Pretreatment with obestatin exhibited a protective effect in the colon, leading to a reduction of colonic damage in acetic acid-induced colitis. This effect was associated with an improvement of mucosal blood flow, an increase in mucosal cell proliferation, and a decrease in local in flammation.

Key words: cell proliferation, blood flow, myeloperoxidase, interleukin-1ß.

\author{
Corresponding author: \\ Piotr Ceranowicz MD, PhD \\ Department of Physiology \\ Jagiellonian University \\ Medical College \\ 16 Grzegórzecka St \\ 31-531 Krakow, Poland \\ Phone: +48124211006 \\ Fax: +48 124225478 \\ E-mail: \\ mpcerano@cyf-kr.edu.pl
}




\section{Introduction}

Inflammatory bowel disease (IBD), the main types of which are Cohn's disease and ulcerative colitis, is a group of chronic inflammations of the digestive tract [1]. They are characterized by a phasic course, with alternate periods of exacerbation and remission. According to epidemiological studies the incidence of IBD is constantly rising [1-4]. Although the etiology of IBD is still unclear, available studies suggest that IBD results from an abnormal immunological response to microflora present in the digestive system, and their pathogenesis is complex, requiring the co-existence of environmental and genetic factors $[1,4,5]$. There are numerous methods to ameliorate the signs and symptoms of IBD, but there is no method to permanent cure this disease $[1,5,6]$. This leads to a search for new therapeutic strategies.

Obestatin is a 23-amino acid peptide, discovered in rat stomach and derived from preproghrelin, which is a common prohormone for ghrelin and obestatin [7, 8]. Secretion of obestatin is pulsatile and displays an ultradian rhythmicity similar to ghrelin and growth hormone [9]. Obestatin exhibits opposite effects to ghrelin on gastrointestinal motility and energy metabolism. It has been reported to be an anorexic hormone, reducing food intake, gastric emptying time, jejunal motility, and body weight gain [8-13].

Previous studies have shown that obestatin exhibits protective and therapeutic effects in some organs of the gut [8]. It has been shown that treatment with obestatin accelerates the healing of acetic acid induced gastric ulcers [14]. The therapeutic effect of obestatin has also been found in experimental colitis evoked by dextran sodium sulfate [15]. In the pancreas it has been demonstrated that preventive administration of obestatin inhibits the development of cerulein- and ischemia/reperfusion-induced acute pancreatitis $[16,17]$ and accelerates the healing of experimental pancreatitis in rats $[18,19]$. Also obestatin promotes survival of pancreatic islets, especially $\beta$-cells [20]. Moreover, clinical studies have shown that the obestatin/ghrelin ratio could serve as an index of IBD activity [21, 22].

The objective of the present study was to determine the influence of pretreatment with obestatin on the development of acetic acid-induced colitis in rats.

\section{Material and methods}

\section{Animals and treatment}

The research was performed on Wistar male rats weighing 250-270 g and conducted following the experimental protocol approved by the First Local Commission of Ethics for the Care and
Use of Laboratory Animals in Cracow (Permit No. $2 / 2013$ ). During the study, the animals were kept in cages placed at room temperature and a 12hour light-darkness cycle was maintained. The animals, prior to colitis induction with acetic acid solution, were fasted for $18 \mathrm{~h}$ with free access to water. Before and after this period food and tap water were available ad libitum.

One hundred twenty-eight rats were randomly divided into eight equal experimental groups: (1) control rats treated intraperitoneally (i.p.) with saline without induction of colitis; (2-4) rats treated i.p. with obestatin given at a dose of 4,8 or 16 $\mathrm{nmol} / \mathrm{kg} /$ dose without induction of colitis; (5) rats treated i.p. with saline before induction of colitis; (6-8) rats treated i.p. with obestatin administered at a dose of 4,8 or $16 \mathrm{nmol} / \mathrm{kg} /$ dose before induction of colitis.

The animals from each experimental group were divided into two equal sub-groups. In the first sub-groups, the severity of colitis was assessed $1 \mathrm{~h}$ after the acetic acid enema. In the second subgroups, the severity of colitis was assessed $24 \mathrm{~h}$ after the acetic acid enema.

The experiments were repeated to obtain 8 animals in each experimental group and each time of observation.

Saline or rat obestatin (Yanaihara Institute, Shizuoka, Japan) was administered intraperitoneally according to the group of animals twice, 8 and $1 \mathrm{~h}$ before the rectal administration of saline or acetic acid solution. Obestatin was used at the doses of 4, 8 and $16 \mathrm{nmol} / \mathrm{kg} /$ dose, because previous studies showed that these doses exhibited protective and therapeutic effects in the pancreas [16, 18] and stomach [14]. Obestatin was dissolved in saline and then administered in an amount which did not exceed $0.3 \mathrm{ml} /$ dose.

Before the induction of colitis, animals were anesthetized with ketamine $(50 \mathrm{mg} / \mathrm{kg}$ i.p., Bioketan, Vetoquinol Biowet, Gorzow Wielkopolski, Poland). Colitis was induced by intrarectal administration of $1 \mathrm{ml}$ of $4 \%$ acetic acid aqueous solution through a polyethylene catheter, which end was inserted into the bowel $4.5 \mathrm{~cm}$ deep from the anus. The animals without induction of colitis were treated with saline enema (sham operation).

\section{Measurement of colonic blood flow and mucosal lesions}

One or $24 \mathrm{~h}$ after enema, the rats were anesthetized again with ketamine. After opening the abdominal cavity and exposing the colon, the measurement of colonic blood flow volume was performed using a laser Doppler flowmeter (PeriFlux 4001 Master monitor, Perimed AB, Jarfalla, Sweden), in accordance with the methodology described before [23]. The blood flow measurement 
was performed each time in five different parts of the descending and sigmoid colon and the main value of five records was expressed as the percentage of the value obtained in the animals from the control group. After the measurement of the colonic blood flow, the area of mucosal damage was measured, using a computerized planimeter (Morphomat, Carl Zeiss, Berlin, Germany), in accordance with the method described earlier [24].

\section{Biochemical analysis}

After the measurement of the colonic blood flow and area of lesions, biopsy samples of the colon were taken for determination of mucosal DNA synthesis (an index of mucosal cell proliferation), concentration of pro-inflammatory interleukin-1 $\beta$, activity of myeloperoxidase, and for histological examination.

\section{Determination of DNA synthesis in colonic mucosa}

DNA synthesis was determined by measurement of $\left[{ }^{3} \mathrm{H}\right]$ thymidine incorporation $([6-3 \mathrm{H}]$-thymidine, 20-30 Ci/mmol, Institute for Research, Production and Application of Radioisotopes, Prague, Czech Republic) into the mucosal DNA as described previously [25]. The incorporation of labeled thymidine into DNA was determined by counting $0.5 \mathrm{ml}$ of DNA-containing supernatant in a liquid scintillation system. The rate of DNA synthesis was expressed as a number of tritium disintegrations per minute per $\mu \mathrm{g}$ of DNA (dpm/ $\mu \mathrm{g}$ DNA).

\section{Determination of interleukin-1 $\beta$ concentration in colonic mucosa}

The samples of the colonic mucosa were homogenized in ice-cold phosphate-buffered saline (PBS, $20 \mathrm{mM}, \mathrm{pH}$ 7.4). The homogenate was centrifuged at $1,500 \mathrm{~g}$ for $10 \mathrm{~min}$ at $4^{\circ} \mathrm{C}$. The content of interleukin- $1 \beta$ in the supernatant was measured using the Rat IL-1 $\beta$ Platinum Elisa (Bender MedSystem $\mathrm{GmbH}$, Vienna, Austria). The concentration of interleukin-1 $\beta$ in colonic mucosa was expressed as ng per $g$ of tissue.

\section{Determination of myeloperoxidase activity in colonic mucosa}

The samples of colonic mucosa were frozen in liquid nitrogen, and, until the measurement was done, stored at $-60^{\circ} \mathrm{C}$. Myeloperoxidase activity was assessed using a modification of the method described by Bradley et al. [26]. The mucosa was homogenized in $1 \mathrm{ml}$ of $50 \mathrm{mM}$ potassium phosphate buffer ( $\mathrm{pH}$ 6.0) containing $0.5 \%$ of hexadecyltrimethyl ammonium bromide. Then the homogenate was freeze-thawed three times, subjected to sonication in an ice bath for $20 \mathrm{~s}$ and centrifuged at $30,000 \mathrm{~g}$ for $15 \mathrm{~min}$ at $4^{\circ} \mathrm{C} .100 \mu \mathrm{l}$ of the supernatant was taken and $2.9 \mathrm{ml}$ of $50 \mathrm{mM}$ phosphate buffer was added, which contained $157 \mu \mathrm{g} /$ $\mathrm{ml}$ of o-dianisidine dihydrochloride and $0.0005 \%$ hydrogen peroxide. Hydrogen peroxide reduction through myeloperoxidase causes oxidation of o-dianisidine and produces a stained final product. The intensity of staining was measured spectrophotometrically with a light wavelength of $460 \mathrm{~nm}$. The obtained results were calculated in units per gram of tissue and finally expressed as the percentage of the value observed in the control group.

\section{Histological examination of the colon}

Samples of the colon were fixed in $10 \%$ buffered formaldehyde and embedded in paraffin. Paraffin sections were stained with hematoxylin and eosin. Slides were examined by two experienced pathologists without knowledge of the treatment given. The histological grading of colonic damage was determined using a scale previously presented by Vilaseca et al. [27]. The histological grading of lesions was made using a scale ranging from 0 to 2 ( 0 = no lesions; $1=$ small lesions $<3 \mathrm{~mm} ; 2$ = large lesions > $3 \mathrm{~mm}$ ). Inflammatory infiltration was graded from 0 to $3(0=$ none; 1 small; 2 = moderate; 3 = heavy), depth of the lesions was graded from 0 to 3 ( 0 = no lesions; 1 = lesions reaching submucosa; 2 = lesions reaching muscularis propria; 3 = lesions reaching serosa). The presence of fibrosis was grading from 0 to 2 ( 0 = none; 1 = mild; 2 = severe $)$.

\section{Statistical analysis}

The results were presented as the main value \pm standard error (SEM). Statistical assessment was performed through one-way analysis of variance followed by Tukey's multiple comparison test using GraphPad Prism (GraphPad Software, San Diego, CA, USA). Statistical analysis was performed separately for each time of observation. Differences were considered to be statistically significant if $p$ was less than 0.05 .

\section{Results}

In the control saline-treated animals without induction of colitis, no lesions of the colon were observed in macroscopic or microscopic examination (Figures 1 and 2; Table I). Also administration of obestatin was without an effect on colonic morphology in rats without induction of colitis (Figure 1; Table I). Rectal administration of $4 \%$ solution of acetic acid led to induction of colitis in all rats. In rats treated with saline, $1 \mathrm{~h}$ after the induction of colitis, the mucosal damage area was 4.9 $\pm 0.4 \mathrm{~mm}^{2}$, whereas after the next $23 \mathrm{~h}$ the area 


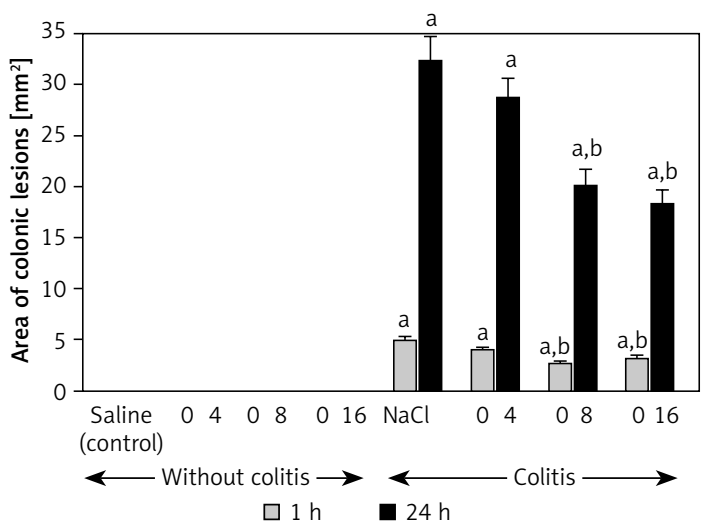

Figure 1. Influence of pretreatment with obestatin given intraperitoneally at a dose of 4,8 or $16 \mathrm{nmol} /$ $\mathrm{kg} /$ dose $(\mathrm{O} 4, \mathrm{O} 8$ or $\mathrm{O} 16)$ on the area of colonic lesions observed 1 or $24 \mathrm{~h}$ after induction of colitis Mean \pm standard error. $N=8$ animals in each group. ${ }^{a} p<0.05$ compared to control at the same time of observation; ${ }^{b} p<0.05$ compared to $\mathrm{NaCl}+$ colitis at the same time of observation
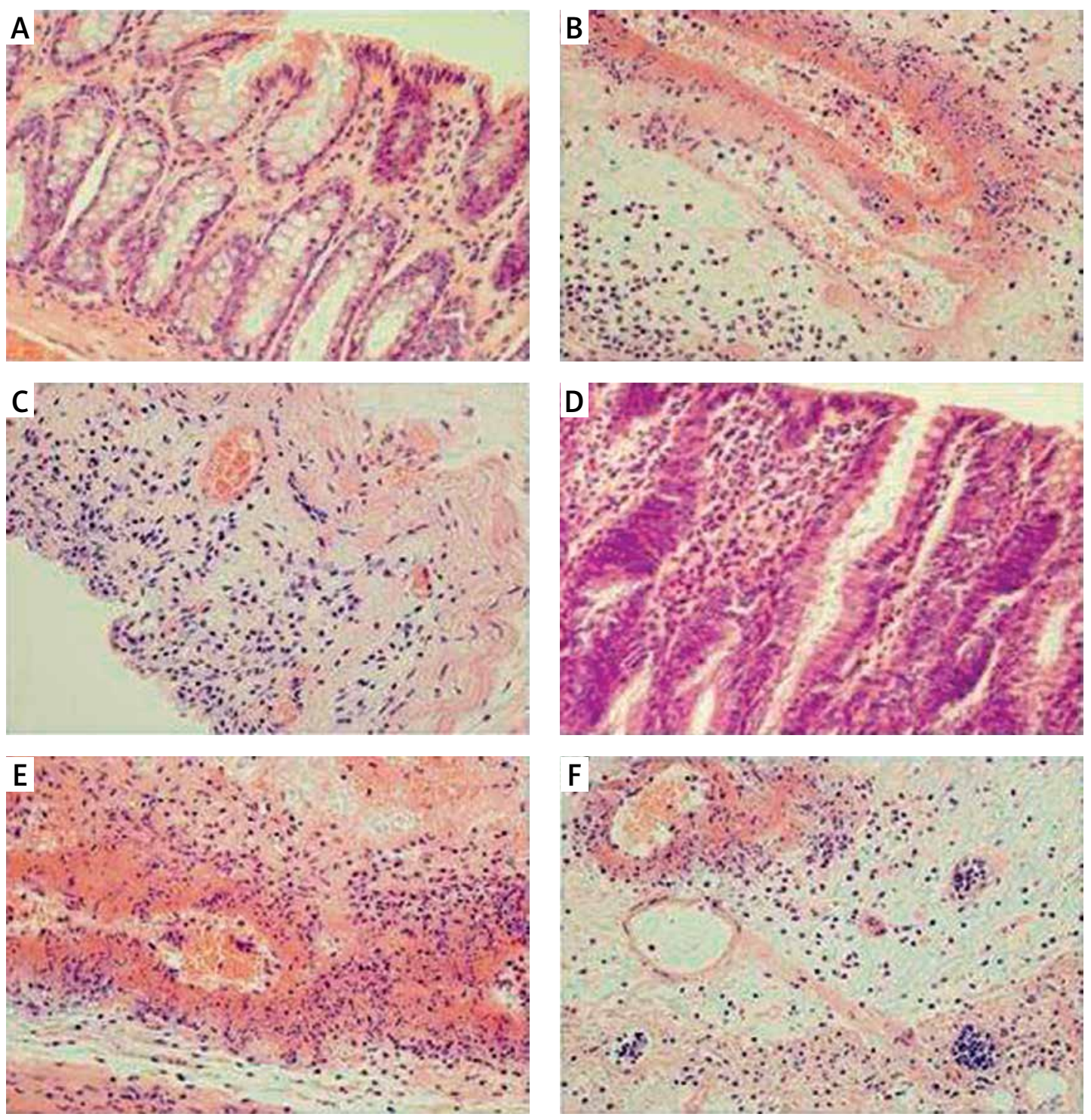

Figures 2. A - Representative microscopic image of colonic mucosa observed $1 \mathrm{~h}$ after enema with saline in saline-pretreated control rats. B - Representative microscopic image of colonic mucosa observed $1 \mathrm{~h}$ after enema with acetic acid solution in saline-pretreated rats. C - Representative microscopic image of colonic mucosa observed $1 \mathrm{~h}$ after enema with acetic acid solution in rats pretreated with obestatin given at a dose of $8 \mathrm{nmol} / \mathrm{kg} /$ dose. D - Representative microscopic image of colonic mucosa observed $24 \mathrm{~h}$ after enema with saline in saline-pretreated control rats. $\mathrm{E}$ - Representative microscopic image of colonic mucosa observed $24 \mathrm{~h}$ after enema with acetic acid solution in saline-pretreated rats. F-Representative microscopic image of colonic mucosa observed $24 \mathrm{~h}$ after enema with acetic acid solution in rats pretreated with obestatin given at a dose of $8 \mathrm{nmol} / \mathrm{kg} / \mathrm{dose}$. Hematoxylin-eosin stain. Original magnification 400x 
Table I. Morphological signs of colonic damage observed 1 or $24 \mathrm{~h}$ after rectal administration of saline or acetic acid solution (colitis) in rats pretreated with saline or obestatin given at a dose of 4,8 or $16 \mathrm{nmol} / \mathrm{kg} / \mathrm{dose}$ (obestatin 4 , obestatin 8 or obestatin 16$)$

\begin{tabular}{|c|c|c|c|c|}
\hline \multirow[t]{2}{*}{ Variable } & \multicolumn{4}{|c|}{ Morphological changes } \\
\hline & $\begin{array}{c}\text { Grading of colonic } \\
\text { damage } \\
(0-2)\end{array}$ & $\begin{array}{c}\text { Inflammatory } \\
\text { infiltration } \\
(0-3)\end{array}$ & $\begin{array}{l}\text { Depth of damage } \\
(0-3)\end{array}$ & $\begin{array}{c}\text { Fibrosis } \\
(0-3)\end{array}$ \\
\hline \multicolumn{5}{|l|}{$1 \mathrm{~h}:$} \\
\hline Saline (control) & 0 & 0 & 0 & 0 \\
\hline Obestatin 4 & 0 & 0 & 0 & 0 \\
\hline Obestatin 8 & 0 & 0 & 0 & 0 \\
\hline Obestatin 16 & 0 & 0 & 0 & 0 \\
\hline Saline + colitis & 2 & 2 & 2 & 1 \\
\hline Obestatin $4+$ colitis & $1-2$ & 2 & 2 & 1 \\
\hline Obestatin $8+$ colitis & 1 & $1-2$ & 1 & 1 \\
\hline Obestatin $16+$ colitis & 1 & $1-2$ & 1 & 1 \\
\hline \multicolumn{5}{|l|}{$24 \mathrm{~h}:$} \\
\hline Saline (control) & 0 & 0 & 0 & 0 \\
\hline Obestatin 4 & 0 & 0 & 0 & 0 \\
\hline Obestatin 8 & 0 & 0 & 0 & 0 \\
\hline Obestatin 16 & 0 & 0 & 0 & 0 \\
\hline Saline + colitis & 2 & 3 & $2-3$ & 2 \\
\hline Obestatin $4+$ colitis & $1-2$ & $2-3$ & 2 & 1 \\
\hline Obestatin $8+$ colitis & $1-2$ & 2 & 1 & 1 \\
\hline Obestatin $16+$ colitis & $1-2$ & 2 & 1 & 1 \\
\hline
\end{tabular}

Numbers represent the predominant histological grading in each group.

of colonic lesions enlarged to $32.3 \pm 2.5 \mathrm{~mm}^{2}$ (Figure 1). In saline-treated animals with colitis, histological examination performed $1 \mathrm{~h}$ after acetic acid enema showed the presence of large lesions reaching the level of the muscular membrane, with moderate inflammatory infiltration (Table I). Twenty-three hours later, histological examination showed an increase in the severity of colonic damage. There were large lesion ulcers, reaching the muscular or serous membrane. These lesions were accompanied by severe inflammatory infiltration (Table I, Figure 2). In rats with colitis, pretreatment with obestatin reduced the development of colonic damage. One hour after induction of colitis, the area of colonic damage was reduced by $19 \%, 45 \%$ or $35 \%$ in rats pretreated with obestatin given at a dose of 4,8 or $16 \mathrm{nmol} / \mathrm{kg} /$ dose, respectively. Twenty-three hours later, the area of the colonic lesion was reduced by $11 \%, 38 \%$ or $44 \%$ depending on the dose of obestatin (Figure 1). The reduction in the area of colonic damage evoked by obestatin given at a dose of 8 and $16 \mathrm{nmol} / \mathrm{kg} /$ dose was sta- tistically significant in both times of observation, 1 and $24 \mathrm{~h}$ after induction of colitis.

Pretreatment with obestatin also reduced histological manifestation of colonic damage evoked by acetic acid (Table I, Figure 2). One hour after induction of colitis, the protective effect of pretreatment with obestatin was found as a decrease in grading and depth of lesions, as well as a reduction in inflammatory infiltration of the colonic wall. Twenty-three hours later, the beneficial effect of pretreatment with obestatin was manifested, apart from the effects mentioned above, by inhibition of fibrosis development (Table I, Figure 2).

In the animals from the control group, DNA synthesis in colonic mucosa reached the value of $38.2 \pm 1.9$ and $37.5 \pm 2.8 \mathrm{dpm} / \mu \mathrm{g}$ DNA at the time of 1 and $24 \mathrm{~h}$ after the saline enema, respectively (Figure 3). Pretreatment with obestatin, in the dosage used, did not exhibit a statistically significant influence on the dynamics of DNA replication in colonic mucosa in animals without induction of colitis. One and $24 \mathrm{~h}$ after the rectal adminis- 
tration of acetic acid solution, DNA synthesis was significantly reduced by around $50 \%$ and $62 \%$, respectively. Prior administration of obestatin partially reversed that effect. Pretreatment with obestatin given at a dose of 8 or $16 \mathrm{nmol} / \mathrm{kg} /$ dose led to a statistically significant, similar in the case of both doses, improvement of DNA replication in the colon mucous membrane, in the animals with colitis. This effect was observed at both times of observation, 1 and $24 \mathrm{~h}$ after the induction of colitis (Figure 3). In contrast, pretreatment with obestatin given at a dose of $4 \mathrm{nmol} / \mathrm{kg} /$ dose was without an effect on mucosal DNA synthesis in the colon of rats with acetic acid-induced colitis (Figure 3).

In the groups of animals without the induction of colitis, double intraperitoneal administration of obestatin in the doses used failed to affect the mucosal blood flow in the colon (Figure 4). Induction of colitis led to a statistically significant decrease in the blood flow through the colonic mucosa by almost $72 \%$ and $77 \%$, respectively after 1 and $24 \mathrm{~h}$ after the enema with acetic acid solution (Figure 4). Prior double administration of obestatin, given at a dose of 8 or $16 \mathrm{nmol} / \mathrm{kg} /$ dose, significantly reversed the colitis-evoked decrease in the mucosal blood flow in the colon. This effect of obestatin was found at both times of observation, 1 and $24 \mathrm{~h}$ after the induction of colitis. The effect of obestatin administered at a dose of $4 \mathrm{nmol} / \mathrm{kg} /$ dose on mucosal blood flow was weak and statistically insignificant (Figure 4).

In the control rats, mucosal concentration of pro-inflammatory IL-1 $\beta$ in the colon was around $0.80 \mathrm{ng} / \mathrm{g}$ of tissue (Figure 5). Treatment with any dose of obestatin was without a significant effect on the mucosal IL-1 $\beta$ level in the rats without coli-

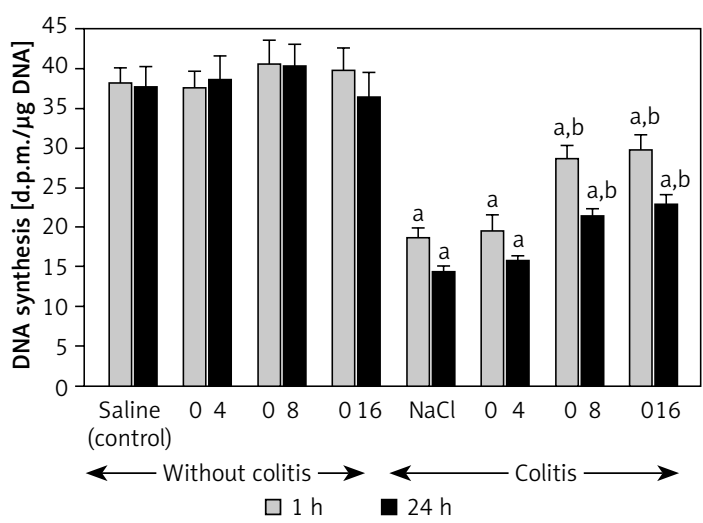

Figure 3. Influence of pretreatment with obestatin given intraperitoneally at a dose of 4,8 or $16 \mathrm{nmol} /$ $\mathrm{kg} /$ dose $(\mathrm{O} 4, \mathrm{O} 8$ or 016$)$ on DNA synthesis in colonic mucosa observed 1 or $24 \mathrm{~h}$ after induction of colitis

Mean \pm standard error. $N=8$ animals in each group ${ }^{a} p<0.05$ compared to control at the same time of observation; ${ }^{b} \mathrm{p}<0.05$ compared to $\mathrm{NaCl}+$ colitis at the same time of observation. tis. Administration of $4 \%$ solution of acetic acid increased the mucosal IL-1 $\beta$ concentration by $50 \%$ and $600 \%$ at 1 and $24 \mathrm{~h}$ after induction of colitis, respectively. Pretreatment with obestatin at a dose of 8 and $16 \mathrm{nmol} / \mathrm{kg} /$ dose reduced the colitis-evoked increase in mucosal IL-1 $\beta$ concentration. This effect was statistically significant at 1 and $24 \mathrm{~h}$ after induction of colitis in rats pretreated with obestatin given at a dose of $16 \mathrm{nmol} /$ $\mathrm{kg} /$ dose. In the case of animals pretreated with obestatin given at a dose of $8 \mathrm{nmol} / \mathrm{kg} / \mathrm{dose}$, a significant reduction in mucosal IL- $1 \beta$ concentration was observed $24 \mathrm{~h}$ after induction of colitis. One hour after induction of colitis, pretreatment with obestatin given at a dose of $8 \mathrm{nmol} / \mathrm{kg} / \mathrm{dose}$ reduced mucosal IL-1 $\beta$ concentration, but this effect was statistically insignificant in comparison to the value observed in saline-treated animals with colitis (Figure 5). Pretreatment with obestatin administered at a dose of $4 \mathrm{nmol} / \mathrm{kg} /$ dose failed to affect the mucosal concentration of IL-1 $\beta$ in the colon of animals with colitis (Figure 5).

Administration of obestatin given at the doses used failed to have a significant effect on the mucosal myeloperoxidase (MPO) activity in the colon of rats without induction of colitis (Figure 6). One hour after the enema with acetic acid, MPO activity in colonic mucosa was increased almost by $100 \%$, whereas $23 \mathrm{~h}$ later almost a 5 -fold increase in MPO activity in colonic mucosa was observed. Pretreatment with obestatin reduced the colitis-evoked increase in colonic activity of MPO. The effect of obestatin, administered at a dose of $4 \mathrm{nmol} / \mathrm{kg} /$ dose, was statistically insignificant at both times of observation. In contrast, obestatin given at a dose of 8 or $16 \mathrm{nmol} / \mathrm{kg} /$ dose signifi-

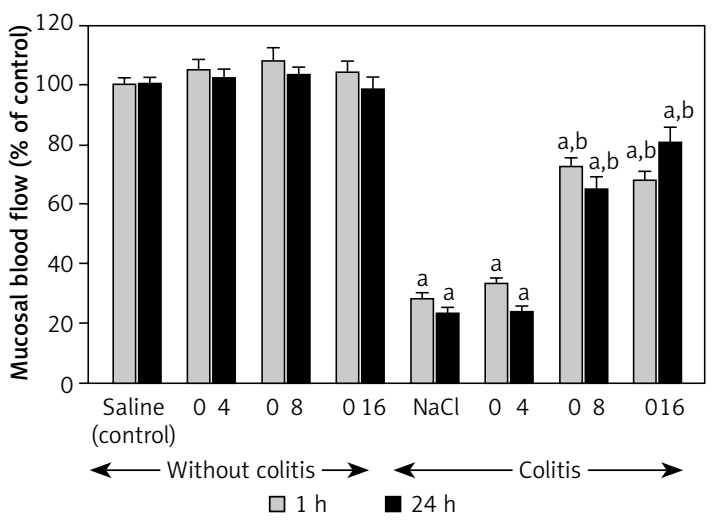

Figure 4. Influence of pretreatment with obestatin given intraperitoneally at a dose of 4,8 or 16 $\mathrm{nmol} / \mathrm{kg} /$ dose $(04,08$ or 016$)$ on mucosal blood flow in the colon observed 1 or $24 \mathrm{~h}$ after induction of colitis

Mean \pm standard error. $N=8$ animals in each group ${ }^{a} p<0.05$ compared to control at the same time of observation; ${ }^{b} p<0.05$ compared to $\mathrm{NaCl}+$ colitis at the same time of observation. 


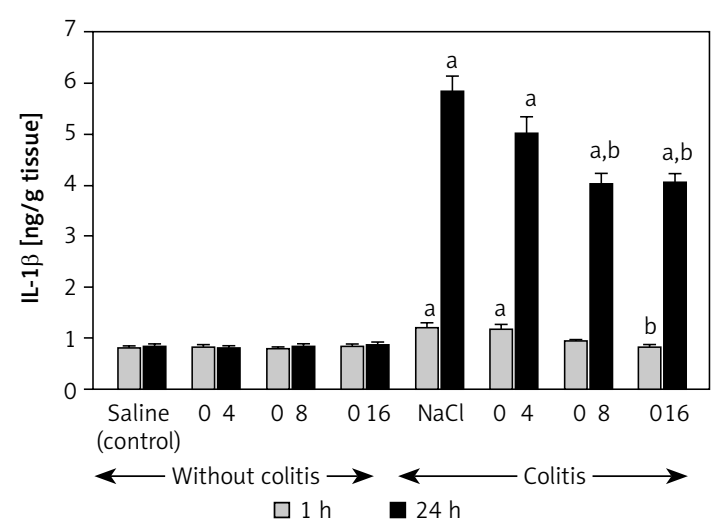

Figure 5. Influence of pretreatment with obestatin given intraperitoneally at a dose of 4,8 or $16 \mathrm{nmol} /$ $\mathrm{kg} /$ dose $(04,08$ or 016$)$ on interleukin- $1 \beta$ concentration in colonic mucosa observed 1 or $24 \mathrm{~h}$ after induction of colitis

Mean \pm standard error. $N=8$ animals in each group. ${ }^{a} p<0.05$ compared to control at the same time of observation; ${ }^{b} p<0.05$ compared to $\mathrm{NaCl}+$ colitis at the same time of observation.

cantly inhibited the mucosal MPO activity in the colon of the animals with colitis. This inhibitory effect was similar for both above doses of obestatin and was observed at both 1 and $24 \mathrm{~h}$ after the induction of colitis (Figure 6).

\section{Discussion}

This study provided important observations showing that obestatin affects maintenance of the integrity of the mucous membrane in the colon. Pretreatment with obestatin inhibited the development of acetic acid-induced colitis in rats, which was found as a decrease in the area of colonic damage. This effect was associated with the improvement of mucosal blood flow and DNA synthesis, and with a reduction in the colitis-evoked increase in mucosal IL-1 $\beta$ concentration and myeloperoxidase (MPO) activity.

Preservation of the integrity of gastrointestinal mucosa is dependent on maintaining a dynamic balance between damaging factors acting on the mucous membrane and mechanisms responsible for mucosa protection. Adequate cell proliferation plays an important role among the mechanisms responsible for integrity of gastrointestinal mucosa. Reduction in cell proliferation, excessive apoptosis and increased cell loss play a key role in the development of mucous membrane atrophy and ulcers $[28,29]$. On the other hand, increased cell renewal leads to increased mucosal protection in the gastrointestinal tract and promotes healing of the damage in the gut [30-33]. Mucosal cells are reconstructed by mitosis of stem and progenitor cells. DNA synthesis occurs in the $\mathrm{S}$ phase during the cell cycle and it is mandatory for cell division

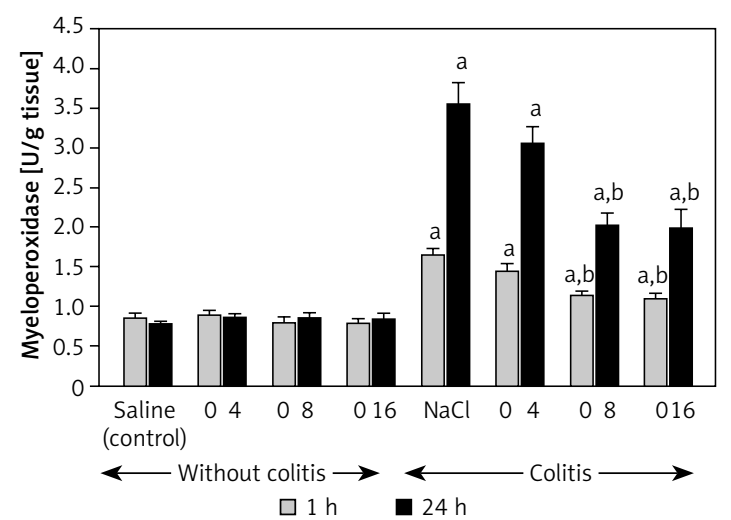

Figure 6. Influence of pretreatment with obestatin given intraperitoneally at a dose of 4,8 or $16 \mathrm{nmol} /$ $\mathrm{kg} /$ dose $(\mathrm{O} 4, \mathrm{O} 8$ or $\mathrm{O16})$ on myeloperoxidase activity in colonic mucosa observed 1 or $24 \mathrm{~h}$ after induction of colitis

Mean \pm standard error. $N=8$ animals in each group ${ }^{a} p<0.05$ compared to control at the same time of observation; ${ }^{b} p<0.05$ compared to $\mathrm{NaCl}+$ colitis at the same time of observation.

[33]. It can be concluded that DNA synthesis dynamics reflect the vitality of cells, as well as cell proliferation. As a result of our present research, it was demonstrated that rectal administration of acetic acid led to a considerable decrease in DNA synthesis in the colonic mucous membrane. That decrease was well correlated with the expanse of the area of inflammation. It indicates that there is a relationship between cell proliferation and pathogenesis of acetic-acid-induced colitis. Our present study has also shown that administration of obestatin in the animals without colitis induction had no significant influence on DNA synthesis in colonic mucosa. This finding indicates that administration of obestatin at these doses does not induce cell hyperproliferation and mucosal hypertrophy in animals with normal mucosa. In contrast to that, pretreatment with obestatin before induction of colitis led to partial, but significant reversion of the colitis-evoked decrease in mucosal DNA synthesis. This observation indicates that improvement of cell vitality and proliferation is involved in the protective effect of obestatin in the colon.

Vascular mechanisms play a key role in the processes of protection and healing of mucosa in the gut [34-36]. Experimental studies have demonstrated that a decrease in gastric blood flow increases the severity and area of gastric ulcers after exposure of gastric mucosa to damaging factors [34]. Similar effects of reduction in organ blood flow on mucosal integrity have been observed in other parts of the digestive tract such as the oral cavity [35], esophagus [36], duodenum [37] and colon [38]. Our present results are in agreement with those observations. Rectal administration 
of acetic acid solution led to a reduction in blood flow in the colon, and this effect was associated with the development of colonic wall damage. Our present study also showed that administration of obestatin prior to colitis induction caused the improvement of blood flow in colonic mucosa, leading to a decrease in the area and severity of colonic mucosa damage. That observation suggests that the protective effect of obestatin on the colonic mucosa is related, at least in part, to improvement of blood flow in this membrane.

In this study, we evaluated the severity of colitis by measurement of mucosal concentration of IL-1 $\beta$ and MPO activity. IL-1 $\beta$ plays an essential role in the development of local and systemic inflammation [39]. This pro-inflammatory cytokine is mainly produced by monocytes and tissue macrophages. Interleukin-1 $\beta$ is involved in mediating both acute and chronic inflammation. It initiates the inflammatory cascade by activating the expression of further pro-inflammatory cytokines, mainly interleukin-6, TNF- $\alpha$ and prostaglandins $[39,40]$. Interleukin- $1 \beta$ is synthesized in immature form, which is proteolytically processed to its active form by caspase-1 [41]. The interleukin-1 gene cluster has been mapped to the long arm of chromosome 2 and consists of three genes, $\mathrm{IL}-1 \alpha, \mathrm{IL}-1 \beta$ and IL- 1 receptor antagonist genes, encoding IL- $1 \alpha, \mathrm{IL}-1 \beta$ and $\mathrm{IL}-1$ receptor antagonist proteins, respectively [42]. There are studies suggesting that some kinds of polymorphisms in the IL1B gene are associated with an increased risk of diseases such as chronic obstructive pulmonary disease [43] or chronic periodontitis [44]. In the experimental and clinical research, it has been demonstrated that administration of a receptor antagonist or immunoglobulins against IL- $1 \beta$ prevents the increase in IL- 6 and TNF- $\alpha$ in inflammation, as well as decreasing the severity of inflammation [40, 45-48]. Our present study indicated that acetic-acid-induced colitis leads to an increase in mucosal concentration of IL-1 $\beta$ in the colon. Prior administration of obestatin partly, although significantly, reversed that effect. In contrast, administration of obestatin in animals without colitis did not affect IL-1 $\beta$ concentration in colonic mucosa.

The grade of tissue infiltration by neutrophil granulocytes is reflected by the level of MPO activity because it is an enzyme that is present in granularities of these cells $[49,50]$. During inflammation, MPO is released from neutrophils, leading to the creation of hypochlorous acid and other free radicals, which have strong bactericidal and antiviral properties. However, free radicals which are created in this process also cause damage to host cells by destroying proteins, DNA and lipids [50]. In the present research, enema with acetic acid solution led to a significant and potent increase in myeloperoxidase activity in the colonic mucosa. Prior administration of obestatin, in animals in which colitis was induced, led to a significant reduction in the colitis-evoked increase in MPO activity in the colonic mucosa. On the other hand, administration of obestatin failed to affect MPO activity in the colonic mucosa in animals in which colitis was not induced.

The effects of obestatin on IL-1 $\beta$ concentration and MPO activity in colonic mucosa in rats with colitis suggest that the protective effect of obestatin is related to the inhibitory impact on the development of inflammation. The lack of effects of pretreatment with obestatin on mucosal IL-1 $\beta$ and MPO in animals without colitis suggests that this polypeptide has no influence on the immune system activity, as well as migration, and activity of leukocytes in the colon without inflammation.

In conclusion, our present results indicate that pretreatment with obestatin protects the colonic mucosa against acetic acid-induced damage. This observation suggests the potential applicability of this peptide in maintenance of IBD patients in remission.

\section{Acknowledgments}

Publication fee was covered by KNOW.

\section{Conflict of interest}

The authors declare no conflict of interest.

\section{References}

1. Stenson WF, Hanauer SB, Cohen RD. Inflammatory bowel disease. In: Textbook of gastroenterology. Fifth edition. Yamada T, Alpers DH, Kalloo AN, Kaplowitz N, Owyang C, Powell DW (eds). Wiley-Blackwell, Chichester 2009; 1386-472.

2. Tsironi E, Feakins RM, Probert CS, Rampton DS, Phil D. Incidence of inflammatory bowel disease is rising and abdominal tuberculosis is falling in Bangladeshis in East London, United Kingdom. Am J Gastroenterol 2004; 99 : 1749-55.

3. Molodecky NA, Soon IS, Rabi DM, et al. Increasing incidence and prevalence of the inflammatory bowel diseases with time, based on systematic review. Gastroenterology 2012; 142: 46-54.

4. Ng SC, Bernstein CN, Vatn MH, et al. Geographical variability and environmental risk factors in inflammatory bowel disease. Gut 2013; 62: 630-49.

5. Baumgart DC. The diagnosis and treatment of Crohn's disease and ulcerative colitis. Dtsch Arztebl Int 2009; 106: 123-33.

6. Baumgart DC, Sandborn WJ. Crohn's disease. Lancet 2012; 380: 1590-605.

7. Zhang JV, Ren PG, Avsian-Kretchmer O, et al. Obestatin, a peptide encoded by the ghrelin gene, opposes ghrelin's effects on food intake. Science 2005; 310: 996-9.

8. Ceranowicz P, Warzecha Z, Dembiński A. Peptidyl hormones of endocrine cells origin in the gut - their dis- 
covery and physiological relevance. J Physiol Pharmacol 2015; 66: 11-27.

9. Zizzari P, Longchamps R, Epelbaum J, et al. Obestatin partially affects ghrelin stimulation of food intake and growth hormone secretion in rodents. Endocrinology 2007; 148: 1648-53.

10. Dembiński A, Warzecha Z, Ceranowicz P, et al. Variable effect of ghrelin administration on pancreatic development in young rats. Role of insulin-like growth factor-1. J Physiol Pharmacol 2005; 56: 555-70.

11. Warzecha Z, Dembiński A. Protective and therapeutic effects of ghrelin in the gut. Curr Med Chem 2012; 19: 118-25.

12. Zhang JV, Ren PG, Vsian-Kretchmer O, et al. Obestatin, a peptide encoded by the ghrelin gene, opposes ghrelin's effects on food intake. Science 2005; 310: 996-9.

13. Chen CY, Asakawa A, Fujimiya M, Lee SD, Inui A. Ghrelin gene products and the regulation of food intake and gut motility. Pharmacol Rev 2009; 61: 430-81.

14. Dembiński A, Warzecha Z, Ceranowicz P, et al. Administration of obestatin accelerates the healing of chronic gastric ulcers in rats. Med Sci Monit 2011; 17: BR196-200.

15. Pamukcu O, Kumral ZN, Ercan F, Yegen BC, Ertem D. Anti-inflammatory effect of obestatin and ghrelin in dextran sulfate sodium-induced colitis in rats. J Pediatr Gastroenterol Nutr 2013; 57: 211-8.

16. Ceranowicz P, Warzecha Z, Dembinski A, et al. Pretreatment with obestatin inhibits the development of cerulein-in duced pancreatitis. J Physiol Pharmacol 2009; 60: 95-101.

17. Bukowczan J, Warzecha Z, Ceranowicz P, Kuśnierz-Cabala B, Tomaszewska R, Dembinski A. Pretreatment with obestatin reduces the severity of ischemia/reperfusion-induced acute pancreatitis in rats. Eur J Pharmacol 2015; 760: 113-21.

18. Bukowczan J, Warzecha Z, Ceranowicz P, Kuśnierz-Cabala B, Tomaszewska R. Obestatin accelerates the recovery in the course of ischemia/reperfusion-induced acute pancreatitis in rats. PLoS One 2015; 10: e0134380.

19. Bukowczan J, Cieszkowski J, Warzecha Z, et al. A. Therapeutic effect of obestatin in the course of cerulein-induced acute pancreatitis. Pancreas 2015 Oct 15 [Epub ahead of print].

20. Granata R, Settanni F, Gallo D, et al. Obestatin promotes survival of pancreatic beta-cells and human islets and induces expression of genes involved in the regulation of beta-cell mass and function. Diabetes 2008; 57: 967-79.

21. Alexandridis E, Zisimopoulos A, Liratzopoulos N, Katsos I, Manolas K, Kouklakis G. Obestatin/ghrelin ratio: a new activity index in inflammatory bowel diseases. Inflamm Bowel Dis 2009; 15: 1557-61.

22. Jung JY, Jeong JB, Kim JW, et al. Circulating ghrelin levels and obestatin/ghrelin ratio as a marker of activity in ulcerative colitis. Intest Res 2015; 13: 68-73.

23. Warzecha Z, Ceranowicz P, Dembinski $M$, et al. Involvement of cyclooxygenase- 1 and cyclooxygenase- 2 activity in the therapeutic effect of ghrelin in the course of ethanol-induced gastric ulcers in rats. J Physiol Pharmacol 2014; 65: 95-106.

24. Dembiński A, Warzecha Z, Ceranowicz P, et al. Role of capsaicin-sensitive nerves and histamine $\mathrm{H} 1, \mathrm{H} 2$, and $\mathrm{H} 3$ receptors in the gastroprotective effect of histamine against stress ulcers in rats. Eur J Pharmacol 2005; 508: 211-21.

25. Warzecha Z, Dembiński A, Brzozowski T, et al. Gastroprotective effect of histamine and acid secretion on ammonia-induced gastric lesions in rats. Scand J Gastroenterol 2000; 35: 916-24
26. Bradley PP, Priebat DA, Christensen RD, Rothstein G. Measurement of cutaneous inflammation: estimation of neutrophil content with an enzyme marker. J Invest Dermatol 1982; 78: 206-9.

27. Vilaseca J, Salas A, Guarner F, Rodríguez R, Martínez M, Malagelada JR. Dietary fish oil reduces progression of chronic inflammatory lesions in a rat model of granulomatous colitis. Gut 1990; 31: 539-44.

28. Greant P, Delvaux G, Willems G. Influence of stress on epithelial cell proliferation in the gut mucosa of rats. Digestion 1988; 40: 212-8.

29. Hall PA, Coates PJ, Ansari B, Hopwood D. Regulation of cell number in the mammalian gastrointestinal tract: the importance of apoptosis. J Cell Sci 1994; 107: 3569-77.

30. Konturek SJ, Dembiński A, Warzecha Z, Brzozowski T, Gregory $\mathrm{H}$. Role of epidermal growth factor in healing of chronic gastroduodenal ulcers in rats. Gastroenterology 1988; 94: 1300-7.

31. Brzozowski T, Konturek PC, Konturek SJ, et al. Effect of local application of growth factors on gastric ulcer healing and mucosal expression of cyclooxygenase- 1 and -2 . Digestion 2001; 64: 15-29.

32. Beckert S, Class N, Farrahi F, Coerper S. Growth hormone enhances gastric ulcer healing in rats. Med Sci Monit 2004; 10: BR255-8.

33. Podolsky DK. Regulation of intestinal epithelial proliferation: a few answers, many questions. Am J Physiol 1993; 264: G179-86.

34. Sørbye H, Svanes K. The role of blood flow in gastric mucosal defence, damage and healing. Dig Dis 1994; 12: 305-17.

35. Warzecha Z, Kownacki P, Ceranowicz P, Dembinski M, Cieszkowski J, Dembinski A. Ghrelin accelerates the healing of oral ulcers in non-sialoadenectomized and sialoadenectomized rats. J Physiol Pharmacol 2013; 64: 657-68.

36. Orlando RC. The integrity of the esophageal mucosa. Balance between offensive and defensive mechanisms. Best Pract Res Clin Gastroenterol 2010; 24: 873-82.

37. Ceranowicz P, Warzecha Z, Dembiński A, et al. Treatment with ghrelin accelerates the healing of acetic acid-induced gastric and duodenal ulcers in rats. J Physiol Pharmacol 2009; 60: 87-98.

38. Leung FW, Su KC, Pique JM, Thiefin G, Passaro EJr, Guth PH. Superior mesenteric artery is more important than inferior mesenteric artery in maintaining colonic mucosal perfusion and integrity in rats. Dig Dis Sci 1992; 37: 1329-35.

39. Dinarello CA. Immunological and inflammatory functions of the interleukin-1 family. Annu Rev Immunol 2009; 27: 519-50.

40. Dinarello CA, Simon A, van der Meer JW. Treating inflammation by blocking interleukin-1 in a broad spectrum of diseases. Nat Rev Drug Discov 2012; 11: 633-52.

41. Choi AJ, Ryter SW. Inflammasomes: molecular regulation and implications for metabolic and cognitive diseases. Mol Cells 2014; 37: 441-8.

42. Nicklin MJ, Weith A, Duff GW. A physical map of the region encompassing the human interleukin-1 alpha, interleukin-1 beta, and interleukin-1 receptor antagonist genes. Genomics 1994; 19: 382-4.

43. Xiao M, Guo L, Wang T, et al. Interleukin-1B-31T/C promoter polymorphism and chronic obstructive pulmonary disease risk: a meta-analysis. Arch Med Sci 2014 10: 434-8.

44. Ma L, Chu WM, Zhu J, Wu YN, Wang ZL. Interleukin-1beta $(3953 / 4) C \rightarrow T$ polymorphism increases the risk of chronic periodontitis in Asians: evidence from a meta- 
analysis of 20 case-control studies. Arch Med Sci 2015; 11: 267-73.

45. Norman J, Franz M, Messina J, et al. Interleukin-1 receptor antagonist decreases severity of experimental acute pancreatitis. Surgery 1995; 117: 648-55.

46. Dinarello CA. A clinical perspective of IL-1beta as the gatekeeper of inflammation. Eur J Immunol 2011; 41: 1203-17.

47. De Koning HD, Schalkwijk J, van der Ven-Jongekrijg J, Stoffels M, van der Meer JW, Simon A. Sustained efficacy of the monoclonal anti-interleukin-1 beta antibody canakinumab in a 9-month trial in Schnitzler's syndrome. Ann Rheum Dis 2013; 72: 1634-8.

48. Herlin T, Fiirgaard B, Bjerre M, et al. Efficacy of anti-IL-1 treatment in Majeed syndrome. Ann Rheum Dis 2013; 72: 410-3.

49. Klebanoff SJ. Myeloperoxidase: friend and foe. J Leukoc Biol 2005; 77: 598-625.

50. Mullane KM, Kraemer R, Smith B. Myeloperoxidase activity as a quantitative assessment of neutrophil infiltration into ischemic myocardium. J Pharmacol Methods 1985; 14: 157-67. 